Pakistan Journal of Humanities and Social Sciences

April - June 2019, Volume 7, No. 2, Pages 219 - 232

\title{
Global Energy Transition and the Role of Energy Mix in Creating Energy Crisis in Pakistan
}

\author{
Jibran Hussain ${ }^{1}$, Sallahuddin Hassan ${ }^{2}$ \\ ${ }^{1}$ Ph.D. Scholar, School of Economics, Finance and Banking, Universiti Utara Malaysia \\ ${ }^{2}$ Professor, School of Economics, Finance and Banking, Universiti Utara Malaysia \\ Email: jibranhr@gmail.com
}

\begin{abstract}
The reliance on non-renewable energy sources is the influence scheming international energy markets and macroeconomic dynamics. Developing economies remain volatile to energy markets due to their heavy reliance on non-renewable energy sources and their low capability to maintain stable energy stock and expensive energy mix, such as Pakistan. The application of autoregressive distributed lag shows that the impact of the energy mix has a significant positive impact on the energy crisis of Pakistan in the long run. Which means that at the macroeconomic perspective only increasing prices of energy have adverse effects, whereas in the short run energy mix shows a significant negative impact on the energy crisis, implying artificial and unsuitable short term ad-hoc adjustments. Therefore, the reluctance in transforming towards the renewable energy sources and ad-hoc adjustments in the formation of the energy mix is a factor of energy crisis in the country.
\end{abstract}

Keywords: Energy Crisis, Energy Mix, Electricity Crisis, Circular Debt

\section{Introduction}

The prevailing history of the world is the antiquity of the brawl for means exploitation. Energy continued as vibrant of the world since the beginning. In a major part of history mankind exclusively remained dependent on food and wood for energy, and there were deficiency and crisis of energy. Though, Chinese erudite in the utilization of coal for energy 4000 years back enabled human to reap coal by 200 BCE (Heinberg, 2005). In the parallel sphere, the Europeans cultured around $200 \mathrm{BCE}$ to extract energy from water and wind (Williams, 2006). In the advent of the first century, the Chinese prospered in harnessing petroleum as an energy source (Chen, 2009). The $10^{\text {th }}$ century watched the concrete evidence of yoking wind and water energy for the purpose of irrigation, water supplies, and grain grinding started with the Persians and reached India and China (Righter, 1996). The $16^{\text {th }}$ century 
England advances coal coke and exploits for iron and steel production and laid the footing of the First Industrial Revolution with the advent of the $17^{\text {th }}$ century. The west endured in the evolution of alteration from production processes to new civilizations all derived from the advancement of sources of energy (Heinberg, 2005). Across the world, resources of energy were escalating, yet its shortage continued tenaciously around the world. Augustine Mouchot in1860 tried primary solar-powered steam generation system to drive the industrial machinery for the first time, which was indeed the earliest industrial consciousness of the insistent energy deficiency (Perlin , 1999). The production of power from a solar panel in 1876 by William G Adams was yet another way of confessing the determined energy crisis and the prominence of an alternate solution. With the beginning of the $19^{\text {th }}$ century, the birth of the modern oil industry started in Texas USA, and changes the dynamics of the energy sector (Paleontological Research Institution, 1900). Yet, unfortunately, a foremost portion of the population continued living under scarce availability of energy, and this deficiency triumphed through the course of the history.

\section{Introduction}

Energy has remained an exceptionally important part of the civilization process. The harnessing of sunlight was the original source of energy. The primitive caveman learned the use of woods for multi-purposes until man learned to exploit wind to cross on oceans. However, it was a journey of thousands of years where human beings developed windmills and water wheels for extracting energy. The Egyptians lighted their homes with the floating oil and Americans started warming up their homes with coal, whereas the early Chinese used the gas for production of salt, however, solar and woods remain the fundamental sources of energy. In $18^{\text {th }}$ and $19^{\text {th }}$ Century the extraction of natural gas from wells, and usage of coal in the steam engine and boats started transforming the dynamics of daily businesses (NEED, 2010).

An account of economic evolution is beached in the notions of resource acquirement, exploitation, expansion, and competence. Though resource manipulation has been the foundation stone of human reality, the basic heritages of bulk supply deployment started with the industrial revolution. Energy since then is determining the destiny of common people and states. Progress of worldwide trade approaches interactions among nations, refining the welfare of billions around the world trail the track of steady and persistent energy sources. Economic principles provide a significant part in shaping the scope, organization, and operation of the energy markets. The character of energy markets in the economic growth and use of a diversity of strategies and protocols is unavoidable. Energy sanctuary is a huge and precarious 
constituent of the nationwide, local and of the worldwide economy, it is the oxygen of any economy (World Economic Forum, 2012). The oil restriction of 1972/73 and instable prices since World War-II made the landscape of energy more as a strategic good. Today, energy is such a commodity, whose persistent stock is indispensable for economic steadiness and strategic endurance, at the same time its readiness is supplementary with risk and uncertainty. The inconsistent prices and supply of energy have been determining bilateral and regional and economic relations. Energy stability is a global phenomenon. As the population of this planet is snowballing the energy requirement is cumulating with exponential degrees. In today's modern world, the uncertain stream of energy owns a greater threat to national, regional and global stability than anything else.

The procedure of originations and novelties in the contemporary urbane manner of resource utilization and economic growth are in a unique cyclic and contributing association. Invention and innovations in technology and industry influence economic growth, which in response reinforces the former. Hence, this cohesive recurring procedure converts a dynamic strength for socio-economic growth and development. The $1^{\text {st }}$ and the $2^{\text {nd }}$ industrial revolutions were ingrained in the scientific application of steam engine, iron, coal, crude oil, electricity, and internal combustion engines. Whereas, the $3^{\text {rd }}$ was the outcome of expansion in electronics, mass-production methods, competent technologies, further extended by progressions in social sciences, economic policy formulation and structural optimization of economic and energy organizations. World today is passing through $4^{\text {th }}$ industrial revolution, wherein, the character of nanotechnologies, 3D printers, and renewable technological improvements in energy, industry, services, transport, and materials are playing a crucial role in redesigning the facade of this planet. Energy advancement vides technological progression, resource conservation, and persistent efficient green-tech is rendering a crucial role through this alteration and transition. There are civilizations around the globe that did not avail from these revolutions, Pakistan being one of them, for over a span of 15 years is fronting a stark energy crisis, making it defenceless to global energy dynamics. Having a bad track record of political, governance and institutional stability, the country is not being able to coup up with the modern world in terms of technological advancement and resource utilization in general and massive failure in the energy sector in particular. The country is an energy deficient economy, even with a huge prospective of energy resources. Compared to the industrialized nation-states, masses have faced energy deprivation and energy poverty side by side. Countryside electrification is below $1 / 3^{\text {rd }}$ of the communities and business grieves from the wobbly supply as well as load shedding. Pakistan's 
key energy resources are oil, natural gas, hydroelectricity, and coal. A negligible involvement is through nuclear energy, liquefied petroleum gas and unconventional sources such as biogas and solar power. In the countryside, the key source of energy is fuelwood, which puts a huge load upon already wanting forest cover of Pakistan. And this dependence on imported energy is a constant source of wealth shifting abroad, making the local populace poorer day by day.

Energy sources can be classified as renewable and non-renewable based on their capacity and tendency to generate and regenerate energy. Renewable sources of energy have the tendency to generate and regenerate energy, whereas the sources are non-exhaustible in nature. Renewable energy sources go through a chemical transformation and generate as well as regenerate energy (biomass) or physical transformation (water, solar, wind and tidal). Today, more than 18 percent of the world energy supply is produced through renewable energy sources (World Bank, 2014). Renewable energy resources are considered as the lone practical and sustainable source to tackle the ongoing and future energy crisis of the world in general and developing countries in particular. Hence, the world is collectively moving forward towards enhancing the capacity of renewable energy sources that the share of renewables is increasing rapidly as compared to non-renewable sources of energy in the world. The forecast of progress in renewable energy supplies shows that by 2040 the fossil fuels, especially the coal utilization will be replaced, which implies less reliance on the fuel and related petroleum products.

On the other hand, the sources like fossil fuels; oil, gas, and coal are stock of energy developed over millions of years. The main characteristic of these energy sources is their finite stock. These energy sources, being diminishing with their usage, are known as a non-renewable form of energy (Hotelling, 1931). Despite the global transformation towards the development of renewable energy as an alternate energy resource, the age of oil is not over yet. The modern world still relies heavily on non-renewable sources of energy which accounts for more than 81 percent of the total world's energy consumption (World Bank, 2015). The dependence on nonrenewable energy sources is the key factor controlling international oil prices, geo-economic, geo-political and geo-strategic relations, business and macroeconomic dynamics. The developing economies remain volatile to energy shocks due to their heavy dependence on nonrenewables and their low capability to maintain stable energy stock for longer. Pakistan is one of such developing countries that have a heavy dependence on non-renewable energy sources as well as on imported energy. However, this oil dependency has been the result of years of political and institutional instabilities. As in 1971, the country used to import only 15 percent of its total energy use, which has reached to 29 percent in 1999 and by 2015 the country imports 
almost 25 percent of its total net energy use (World Bank, 2015). Due to this, the Pakistani economy remains volatile and vulnerable to international energy dynamics, developments and shocks. However, the world is going through a transition phase, the global community at the United Nations (UN) professed 2014-2024 as "the decade of sustainable energy for all" (UN, 2012). To the extension of UN-Energy Summit (2012), the global leaders agreed to diminution the enslavement on non-renewable energy sources, especially after the global consensus on Sustainable Development Goals (SDGs) in 2016 at UN submit on SDGs. The provision of sustainable, green and cheap energy for all is the seventh goal of SDGs and the only way forward for sustainable future for all.

The objective of this paper is to explore the role of irrational energy mix prevailing in the country as a hurdle to coup up with the world in the process of transition towards renewable. And to analyze the role of energy-mix a factor of energy crisis in the country.

\section{Literature Review}

This line of research on the role of institutions has significant repercussions for both measuring the existing implementation failures as well as explicating the part of policies that are concerned with behavioural disappointments. For instance, if behavioural catastrophes lead to underinvestment in energy sectors competence, then the mark of discounts in energy-related leakages and thefts may be seen in the form of the increasing burden on the exchequer. In parallel, strategies that offer a well-organized means of adjusting the managerial process wellsuited to inducing these relatively well furnished administrative processes. In standard, a group of rules addressing both market and behavioural fiascoes could offer a better effectual general response. In practice, the worth of individual policy components will be contingent on the degree of prevailing market difficulties and capability of precise policies to correct these problems through the development of institutions in a net beneficial manner. The problem of energy crisis in Pakistan is a generic, procedural and behavioural outcome of institutional incompetence, lack of professional and technical capacities, policy operations and implementation failures. Which requires an integrated study to understand complete dynamics. The traditional neo-classical production model is not open enough to explaining the evolutionary behaviours of politics, institutions, especially the energy institutions which integrate and collide to create the problem of the energy crisis. Moreover, the traditional Marxist theory considers restrains and disruption in the accumulation of capital as a crisis. On the other hand, the Capitalist theory of crisis considers the disintegration and dysfunctional of governing system and rule of law. Moreover, Grossman (2014) also sheds light on the Marxist 
approach of crisis that the position in which the structure of the prevailing system is no longer deem fit and reliable, a period of disorder was the credibility, ability of policies, practices, and institutions are called in to question. The explanation of and justification of the concept of energy crisis requires integration of word crisis into the political and economic dynamics of global energy markets. Different researchers have defined the concept of an energy crisis in different ways.

The theoretical basis of the energy crisis in this study is in debt of Ullah et al. (2017). Who has advanced a comprehensive, composite and institutional theory to explain the concept of energy disaster in Pakistan. Based on foundations on New Institutional Economics, authors believed that there are four prevailing significant factors of energy crisis in Pakistan; feeble governance organization, sectoral benefactions, incompetent regulator and unspecified dogmatic institutions. The theory extends solution proposals as in the form of institutional and behavioural reforms for the ongoing crisis. Hence, this study develops the theoretical foundations on EC based on the proposed by the authors there herein.

The oil embargo of 1973, brought the severe economic crisis on to the West (Time, 1979). The incident transformed the dynamics of energy goods and energy markets and energy security became a new global macroeconomic trial. The West rejuvenated its attitude to energy provisions. They framed a cohesive energy strategy, where robust fundamentals were placed to treasure alternatives to oil and fossil fuels, for unrelenting and local energy supply (Luft \& Korin, 2013). The course of events of middle east wars and oil shocks since then remained a reminder for this purpose. North America continued underneath a severe shortage of energy supplies from 2000 to 2008 . The beginning of millennium remained crucial in terms of energy supplies for many countries around the globe, especially the first decade; Zimbabwe, North Korea, Burma, South Africa, China, and Pakistan were all one way or the other persisted subject to severe energy shortage and crisis. Some of those countries like Pakistan are still stressed to deal with the crisis (Kiani, 2006). The lack of access to modern energy resources and services around the world by billions of people, not only hinders the economic process but creates and add up the real problem of energy crisis (Bazilian \& Yumkella, 2015).

Whereas, the conventional investigators are less concerned to explore the relationship of energy with the socio-economic indicators, such as inequality. The prevailing incomplete literature on the subject matter is lacking in connecting energy with growth and wellbeing indicators in case of less developed countries. Goldemberg and Johanson (1995) advocated that energy is a precondition to deliver elementary human necessities to the deprived people around the globe 
and it is a vital element for socio-economic progress. They trust that the role of energy for prosperity is overlooked in conventional United Nations (UN) development agendas over the years, notwithstanding, intensively discussed in Rio world Summit 1992. The UN in the year 2012 called for the world for urgent steps and arrangements to take energy challenges and energy deprivation to achieve the Millennium Development Goals. Gomez-Echeverri (2013) requested for a world-wide act to deal with the energy trial, energy security, and the social issues that cause societies all over the world.

Energy mix reflects the policy and resource strength of any country. Around the world, countries always try to objectify their energy supply and security plan in such a way that the supplies should be sustained, affordable and cost-effective. The fundamental principle of resource economics propagates is rationality in terms of energy resource acquisition, utilization, and distribution. Such as countries with economic prosperity issues should not opt an energy mix, which would lead wealth flows out of the country in the form of energy import bills. The harmony of policies to keep sustainability and affordability of EM requires political will and strong energy institutions (Ullah et al., 2016). Moreover, Gul and Chudhary (2015) also believed that expensive energy mix and energy losses are the biggest contributors to the energy crisis. Therefore, coal resource utilization is a viable solution to decrease the supply-demand breach of energy in Pakistan. This may variate energy mix towards more indigenous energy supplies and share while focusing more on the installation of coal plants, they proposed to change the energy mix to play a vital role in the transition phase.

The existing literature on energy crisis of Pakistan rests with overwhelmingly consensus that existing energy mix of the country is not only economically irrational (Jamali et al., 2011; Haider et al., 2014; Khan \& Abbas, 2016; Hussain, 2018; Rafique \& Rehman, 2017) but also a reflection of existing dearth of political stability and paucity of energy institutional capacity. Consequently, the performance of energy sector despite energy reforms in the early 1990s could not bring any significant change and improvement, hence, been contributing in the misery of energy sector then (Ullah, Arentsen, \& Lovett, 2016; Mirjat et al., 2017). This unjustified, inefficient energy mix when aligned with the transmission and dispatch losses, insufficient tariff structures, ineffective subsidies, and circular debt under make governance structure and weak institutions became the tumour of energy crisis (Malik, 2012; Munir \& Khalid, 2012; Kessides, 2013; Kugelman, 2013).

As, existing energy mix still have almost 68 percent of oil share, with almost no significant improvement in renewable energy technologies and other indigenous energy resources, thus, 
puts a heavy burden on the cost of power production. The existing energy mix is a major cause of energy crisis among others, which requires urgent reforms and restructuring, in order to avoid further crisis. Therefore, a proposal for an optimal energy mix, such that cost of power is PKR10.75 per unit (kWh) while compensating subsidies government provides and would reduce the pressure on circular debt, would reduce blockage among energy production and oil supply corporations and ultimately reduce pressure of ongoing energy crisis (Zameer \& Wang, 2017).

\section{Methodology}

The non-stationarity of time series data is tackled with the Augmented Dicky-Fuller $\left[\Delta y_{t}=\beta_{0}+\gamma y_{t-1}+\beta_{2} t+\sum_{i=1}^{p} \alpha_{i} \Delta y_{t-1}+\varepsilon_{t}\right]$ method, as an efficient econometric test (Nelson \& Plosser, 1982). The optimal lag is selected for the application of Autoregressive Distributed Lag Method $\left(p, q_{1}, q_{2}, q_{3, \ldots} q_{k}\right.$ ), while employing Akaike Information Criterion $\left[A I C_{p}=\frac{-n}{2(1+\log 2 \pi)}-\frac{n}{2 \log \delta^{2}-p}\right]$. The specified ARDL $\left(p, q_{1,} q_{2}, q_{3, \ldots}, q_{k}\right)$ model this study, therefore, conceived in Equation (1);

$$
\begin{gathered}
\Delta E C_{t}=\beta_{0}+\eta E C T_{t}+\sum_{t=1}^{p} \beta_{1} \Delta E C_{t-i}+\sum_{i=0}^{q_{1}} \beta_{2} E M_{t-i}+\sum_{t=0}^{q_{2}} \beta_{3} \Delta G D P G_{t-i}+ \\
\sum_{t=0}^{q_{3}} \beta_{4} \Delta P O P_{t-i}+\gamma_{1} E C_{t-1}+\gamma_{2} E M_{t-1}+\gamma_{3} P O P_{t-1}+\gamma_{4} G D G G_{t-1}+\varepsilon_{t}
\end{gathered}
$$

where $E C$ is an energy crisis, $E M$ is energy mix, GDP is gross domestics product, $P O P$ is population, $\Delta$ denotes change, $\beta_{0}$ is an intercept, $\gamma_{i}$ represents the coefficient of long run order of ARDL $\left(p, q_{i}\right)$, where $i=1,2, \ldots, 7$, on the other hand, $\gamma_{i}$ denotes coefficients of short run order where, $i=1,2, \ldots \ldots, 7$. $\beta_{i}$ represents coefficients, where $i=1,2, \ldots, 7$ of short run order of $\operatorname{ARDL}\left(p, q_{i}\right)$ and $\varepsilon_{t}$ is error term, $\eta$ is coefficient of ECT. The ECT in this model signifies fundamental processes, that the value of this term would define the speed of adjustment to equilibrium in case of any shock.

\section{Results and Discussion}

The Stationary test for the given variables shows enlisted variables are stationary at the first difference. The results for lag length of AIC ( $\left.84.27^{*}\right)$ affirms the three lags. The coefficient of $E M$ in Table 1, is negative and significant as the $p$-value of $\tau$-statistics is less than $\alpha=0.05$, implying a negative long run relationship of $E M$ with $E C$. This implies that the more of thermal energy production it would lead to a reduction of $E C$. Therefore, the impact of increasing government liabilities in the energy supply chain increases the pressure on the crisis. Therefore, implies that increasing liabilities of fuel and energy as an input (mostly imported) the $E C$ situation is going to get worst (Asif, 2011), and a significant deviation from the policy level 
helped in adjusting the supply-demand of energy in the short run, however, in the long run, it created issue of the circular debt (Kessides, 2013). Moreover, the coefficient of GDP is negative and statistically significant as $\alpha=0.05$, therefore, implying that improvement in the economic growth helps in reducing the pressure of $E C$. The economic development of a country depends on various factors; political stability is one of those. Studies indicate an inverse relationship between political stability and economic growth. Whereas, the coefficient of $P O P$ is positive and statistically significant as $\alpha=0.05$, therefore, increasing population is going to create more pressure on the $E C$ in the long run.

Table 1: ARDL Long Run Coefficient Results

\begin{tabular}{|l|r|r|r|c|}
\hline Variable & Coefficient & Std. Error & $\boldsymbol{t}$-Statistic & Prob. \\
\hline EM & -5.68 & 2.34 & -2.43 & $0.02^{*}$ \\
\hline CD & 0.92 & 0.15 & 6.21 & $0.00^{*}$ \\
\hline TDL & 1.84 & 8.89 & 0.21 & 0.84 \\
\hline POP & 0.00 & 0.00 & -0.84 & 0.41 \\
\hline GDPG & -29.33 & 5.54 & -5.30 & $0.00^{*}$ \\
\hline C & 2169.27 & 418.24 & 5.19 & 0.00 \\
\hline
\end{tabular}

Note: * and $* *$ denote the level of significance at 5 percent and 10 percent, respectively.

The coefficient of ECT in Table 2 is negative, less than one and is statistically significant having the $p$-value less than $\alpha=0.05$. Therefore, satisfies all the required conditions for the convergence towards a steady state. The size of the coefficient of the cointegrating equation is -0.94 , is an indication of the speed of adjustment towards the equilibrium, as much as 94 percent of annual convergence, this also indicates that economic agents remove a large percentage of disequilibrium in each period and is significant. The coefficient of $E M$ at the first lag is positive and the $p$-value of $\tau$-statistics is less than five $\alpha=0.05$, thus rejecting the null hypothesis of no short run relationship between $E M$ and $E C$ (Appendix). This implies that greater the deviation of $E M$ from the efficient policy level energy mix (NPP 1994), it would deteriorate the supply-demand dynamics of the energy, therefore is responsible for creating the $E C$ in the country. This outcome not only is aligned with the proposed hypothesis of $E M$ but also supports the evidence of $E C$ prevailed in the country. This result has been the concern of many researchers (Hajiran et al. 2008; Asif, 2009; Khalil \& Zaidi, 2014), where the role of EM as the factor of $E C$ has been discussed as an ad-hoc adjustment in the short term policy measure to settle the energy supply-demand dynamics, which eventually has turnout a catastrophic $E C$ (Kugalman, 2013; Gul \& Chudhry, 2015; Ullah, Arentsen, \& Lovett, 2016).

Table 2: ARDL Short Run Results

\begin{tabular}{|l|r|r|r|r|}
\hline Variable & Coefficient & Std. Error & $\tau$-Statistic & Prob. \\
\hline
\end{tabular}




\begin{tabular}{|l|r|r|r|r|}
\hline $\mathrm{D}(\mathrm{EC}(-1))$ & 0.74 & 0.14 & 5.14 & $0.00^{*}$ \\
\hline $\mathrm{D}(\mathrm{EC}(-2))$ & 0.67 & 0.12 & 5.57 & $0.00^{*}$ \\
\hline $\mathrm{D}(\mathrm{PIS})$ & -10.69 & 7.68 & -1.39 & 0.18 \\
\hline $\mathrm{D}(\mathrm{EM})$ & -2.06 & 2.25 & -0.92 & 0.37 \\
\hline $\mathrm{D}(\mathrm{EM}(-1))$ & 12.21 & 2.76 & 4.42 & $0.00^{*}$ \\
\hline $\mathrm{D}(\mathrm{CD})$ & 1.93 & 0.33 & 5.92 & $0.00^{*}$ \\
\hline $\mathrm{D}($ TDL$)$ & -25.07 & 14.92 & -1.68 & 0.11 \\
\hline $\mathrm{D}(\mathrm{TDL}(-1))$ & -24.03 & 5.76 & -4.17 & $0.00^{*}$ \\
\hline $\mathrm{D}($ POP) & 0.00 & 0.00 & 9.10 & $0.00^{*}$ \\
\hline $\mathrm{D}($ GDPG) & -35.17 & 5.22 & -6.74 & $0.00^{*}$ \\
\hline $\mathrm{D}($ GDPG(-1)) & -7.63 & 4.59 & -1.66 & 0.11 \\
\hline $\mathrm{ECT}(1)$ & -0.94 & 0.21 & -9.08 & $0.00^{*}$ \\
\hline
\end{tabular}

\section{A. Diagnostics}

The Breusch-Godfrey Serial Correlation LM Test is used here in to diagnose the situation of serial correlation. The test hypothesises a null of no serial correlation. The $p$-value $(0.98)$ of $F$-statistics $(0.0004)$ and $p$-value $(0.97)$ observed $\mathrm{R}^{2}(0.001)$ are greater than five percent, thus there is no serial correlation. The Jarque-Bera (1.26) test of normality shows $p$ value (0.522) thus unable to reject the null hypothesis of normality. Therefore, the model has normally distributed residuals. A schematic representation of the Cumulative Sum (CUSUM) and the Cumulative Sum of Square (CUSUMSQ) are also established and fall within the acceptable region with Akaike graph that underpinned our maximum lag selection criterion.

\section{Figure 1: CUSUM and CUSUM of Squares Test}

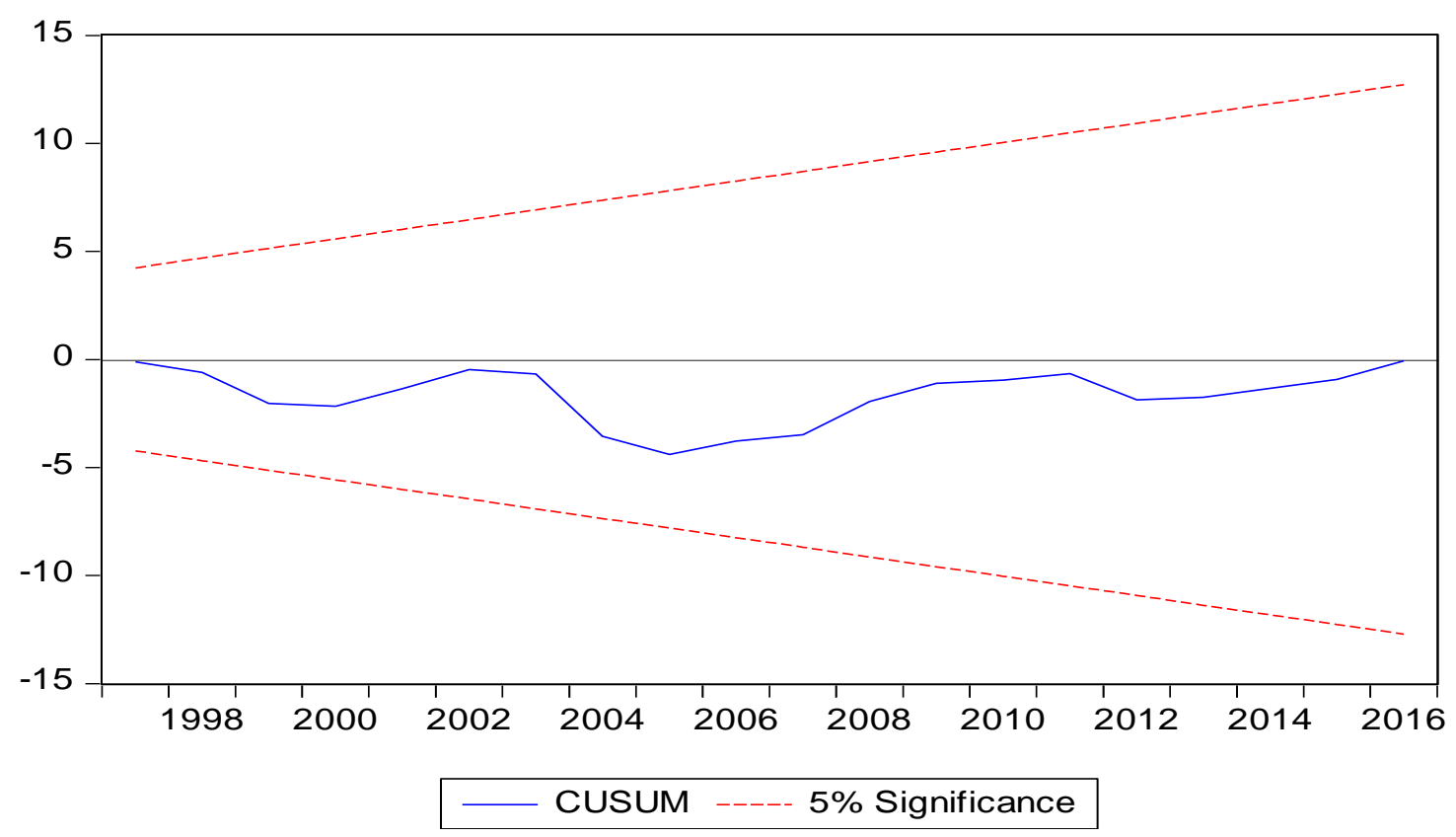




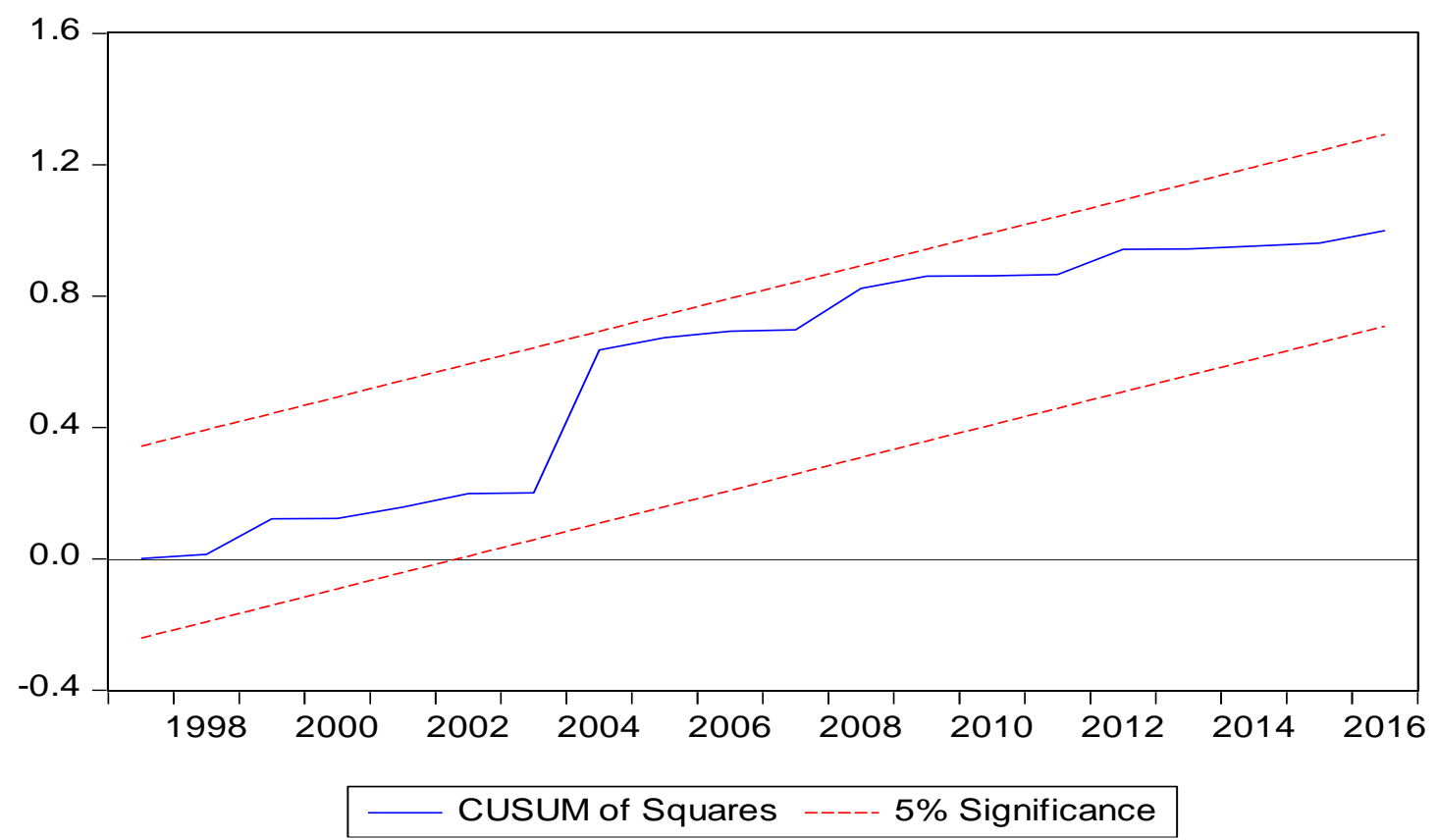

\section{Conclusion and Policy Recommendations}

The impact of energy mix on energy crisis is negative and significant in the short run and significant positive impact in the long run. This reflects the factual situation of the country, where adhoc adjustment is being used to cover the supply-demand gap in the short run to reduce the energy crisis. Which eventually fails to retain the same position in the long run, thus creates more energy crisis after the adjustment periods are over. Therefore, fixing the energy mixed based on national power policy 1994, would reduce the impact of oil price volatilities, the cost of leakages, transmissions losses, therefore, would reduce the pressure of circular debt in the long run and would lay the foundations for the transformation towards green, clean and sustained renewable energy mix. For the purpose, Pakistan must look for a way ahead in such a situation through regional partnerships. The strategic location of the country is a natural dividend for availing the cooperation from her neighborhood countries. By initiating bilateral energy agreements with the Middle East instead of aid, and with Iran on the sustainability of energy supplies with ease would help in as short term adjustment to reduce the energy crisis pressure in the long run. Wherein, the strategic partnership with China as a leader in renewable energy investment could be used as structural support in transforming towards the renewable energy supplies in the long run. The public-private partnership is mandatory to harness the hydro, solar and wind resources of the country to restructure the existing energy mix.

\section{References}


Asif, M. (2009). Sustainable energy options for Pakistan. Renewable and Sustainable Energy Reviews, 13(4), 903-909.

Alahdad, Z. (2012). Pakistan's energy sector: from crisis to crisis: breaking the chain. Pakistan Institute of Development Economics.

Asif, M. (2011). National policy for energy. [Online] Available: http://worldarticles103.blogspot.com/2011/03/national-policy-for-energy-by-masif.html

Bowman, D. M. J. S., et al. 2009. Fire in the Earth system. Science 324:481-484.

Bazilian, M., \& Yumkella, K. (2015). Why energy poverty is the real energy crisis. Global Governance

Chen, L. (2009). Retrieved July 2017, from www.worldenergysource.com : https://alternativeenergy.procon.org/view.source.php?sourceID $=008638$

Federal Energy Regulatory Commision . (2003). Staff report price manipulation in western markets findings at a glance. Federal Energy Regulatory Commision , https://www.ferc.gov/industries/electric/indus-act/wec/enron/summary-findings.pdf.

Dickey, D. A., \& Fuller, W. A. (1979). Distribution of the estimators for autoregressive time series with a unit Gul, M., \& Qureshi, W. A. (2012, July). Long term electricity demand forecasting in residential sector of Pakistan. Power and Energy Society General Meeting, 2012 IEEE (1-7). IEE

root. Journal of the American Statistical Association, 74(366a), 427-431.

Grossman, P. Z. (2014). Energy shocks, crises and the policy process: A review of theory and application. Energy Policy, 77, 56-69.

Gomez-Echeverri, L. (2013). The changing geopolitics of climate change finance. Climate Policy, 13, $632-648$.

Goldemberg, J., \& Johansson, T. B. (1995). Energy as an instrument for socio-economic development.

Haider, A., Ahmed, Q. M., \& Zohaib, J. (2014). Determinants of energy inflation in Pakistan: An empirical analysis. The Pakistan Development Review, 53(4), 491-504.

Harijan, K., Uqaili, M. A., \& Memon, M. (2008). Renewable energy for managing energy crisis in Pakistan. In International Multi Topic Conference (pp. 449-455). Springer, Berlin, Heidelberg.

Heinberg, R. (2005). The Party's Over: Oil, War and the Fate of Industrial Societies (First ed.). Canada: New Society Publishers.

Hotelling, H. (1931). The economics of exhaustible resources. Journal of political Economy. Journal of Political Economy, 39(2), 137-175.

Hussain, J. (2018). Energy sector development: Optimum resource challenges and opportunities. Parliamentary Research Digest, 4(11). 13-22.

Jamali, M. B., Shah, A., Somoro, H. J., Shafique, K., \& Sheikh, F. M. (2011). Oil price shocks: A comparative study on the impacts in purchasing power in Pakistan. Modern Applied Science, 5(2), 192-203.

Malik, A. (2008). Crude oil price, monetary policy and output: The case of Pakistan. The Pakistan Development Review. 47(4), 425-438.

Malik, A. (2012). Power crisis in Pakistan: a crisis in governance? PIDE Monograph Series.

Mirjat, N. H., Uqaili, M. A., Harijan, K., Valasai, G. D., Shaikh, F., \& Waris, M. (2017). A review of energy and power planning and policies of Pakistan. Renewable and Sustainable Energy Reviews, 79, 110-127.

Mirjat, N. H., Uqaili, M. A., Harijan, K., Mustafa, M. W., Rahman, M. M., \& Khan, M. A. (2018). Multi-criteria analysis of electricity generation scenarios for sustainable energy planning in Pakistan. Energies, 11(4), 757. 
Pakistan Journal of Humanities and Social Sciences, 7(2), 2019

Munir, K. A., \& Khalid, S. (2012). Pakistan's power crisis: how did we get here? The Lahore Journal of Economics, 17, 73-82

Khan, M. A., \& Abbas, F. (2016). The dynamics of electricity demand in Pakistan: A panel cointegration analysis. Renewable and Sustainable Energy Reviews (65), 1159-1178.

Luft, G., Korin, A., \& Gupta, E. (2010). Energy security and climate change: a tenuous link. In The Routledge handbook of energy security (pp. 61-73). Routledge.

Kugelman, M. (2013). Pakistan's energy crisis. National Bureau of Asian Research: Washington, $D C$.

Kessides, I. N. (2013). Chaos inpower:Pakistan'selectricitycrisis. Energy Policy(55), 271-285. and Sustainable Energy Reviews, 31, 194-201.

Kostas Bithas, P. K. (2016). Revisiting the energy-development link evidence from 20th century for knowledge base and developing economies. In P. K. Kostas Bithas, Revisiting the Energy-Development Link Evidence from 20th Century for Knowledge Base and Developing Economies. Springer Briefs in Economics.

Kiani, K. (2006). web.archive.org. Retrieved 07 14, 2017, from www.dawn.com: https://web.archive.org/web/20090409133544/http://www.dawn.com/2006/07/29/top 16.htm

NEED. (2010). need.org. Retrieved June 10, 2017, from www.need.org: http://www.need.org/files/curriculum/infobook/historye.pdf

Paleontological Research Institution. (1900). www.priweb.org/"Spindletop Texas,". Retrieved $07 \quad 10, \quad 2017, \quad$ from ww.priweb.org: https://www.priweb.org/ed/pgws/history/spindletop/spindletop2.html

Pesaran, M. H., Shin, Y., \& Smith, R. P. (1999). Pooled mean group estimation of dynamic heterogeneous panels. Journal of the American Statistical Association, 94(446), 621634.

Pesaran MH, Shin Y, Smith RJ (2001) Bounds testing approaches to the analysis of level relationship. Applied Econometrics 16:289-326

Perlin , J. (1999). From Space to Earth: The Story of Solar Electricity. (1999, Trans.) Michigan , USA: aatec publications.

Rafique, M. M., \& Rehman, S. (2017). National energy scenario of Pakistan, current status, future alternatives, and institutional infrastructure: An overview. Renewable and Sustainable Energy Reviews, (69), 156-167.

Righter, R. W. (1996). Wind Energy in America: A History. Oklahama, USA: University of Oklahama Press.

Smil V (2004) World history and energy. In: Clevaland C (ed) Encyclopedia of energy, vol 6. Elsevier, Amsterdam, pp 549-561

Time. (1979). Oil Squeeze. Time, pp. 11-17.

Ullah, K. (2013). Electricity Infrastructure in Pakistan: An overview. International Journal of Energy, Information and Communications, 4(3), 11-26.

Ullah, K., Arentsen, M. J., \& Lovett, J. C. (2016). Institutional determinants of power sector reform in Pakistan. Energy Policy, 102, 332-339.

United Nations. (2012). Sustainable Energy for All. Retrieved from www.un.org: https://www.un.org/press/en/2012/ga11333.doc.htm

Uqaili, M. A., \& Harijan, K. (2011). Energy, environment and sustainable development. Springer Science \& Business Media. New York.

Valasai, G. D., Uqaili, M. A., Memon, H. R., Samoo, S. R., Mirjat, N. H., \& Harijan, K. (2017). Overcoming electricity crisis in Pakistan: A review of sustainable electricity options. Renewable and Sustainable Energy Reviews, 72, 734-745. 
Wiley Online Library . (2018). https://onlinelibrary.wiley.com/doi/pdf/10.1111/j.14682427.1981.tb00556.x. Retrieved 2018, from https://onlinelibrary.wiley.com/doi/pdf/10.1111/j.1468-2427.1981.tb00556

World Bank. (2015). Toward a sustainable energy future for all: directions for the World Bank Group's energy sector. World Bank 's Group Energy Sector. Washington DC: World Bank. Retrieved from http://documents. worldbank.org/curated/en/745601468160524040/pdf/795970SST0Sec M00box377380B00PUBLIC0.pdf

Williams, J. C. (2006, Apr 25). Retrieved July 2017, from www.fi.edu: http://www.cantanpi.org/documents/HistoryofEnergy.pdf

World Economic Forum. (2012). Energy for Economic Growth Energy Vision Update 2012. World Economic Forum. Geneva

Zameer, H., \& Wang, Y. (2017, Sep 15). Energy production system optimization: Evidence from Pakistan. Renewable and Sustainable Energy Reviews(82), 886-893. 